\title{
ASSESSMENT OF THE FRACTURE RISK THROUGH FRACTURE RISK ASSESSMENT TOOL (FRAX) IN POSTMENOPAUSAL WOMEN
}

\author{
E. K. Kirilova1, S. G. Vladeva² \\ ${ }^{1}$ University “Prof. Dr. Assen Zlatarov”, Medical Faculty - Burgas, Bulgaria \\ ${ }^{2}$ Trakia University, Medical Faculty - Stara Zagora, Bulgaria
}

\begin{abstract}
Current National Osteoporosis Foundation (NOF) guidelines recommend treating patients with a 10 -year fracture risk (FRAX) of $\geq 3 \%$ for hip fractures or $\geq 20 \%$ for major osteoporotic fractures to reduce the future fracture risk. The present study investigated the distribution of the women in the groups with a FRAX score for major osteoporotic fractures below $20 \%$ and for hip fractures below 3\%, as well as a FRAX score for major osteoporotic fractures $\geq 20 \%$ and for hip fractures $\geq 3 \%$. We found that women with a fracture risk corresponding to a FRAX score for major osteoporotic fractures $\geq 20 \%$ and with a FRAX score for hip fractures $\geq 3 \%$ were significantly older $(p=0.000)$ and had significantly lower weight and height $(p=0.000)$ compared to women with FRAX score for major osteoporotic fractures below $20 \%$ and with a FRAX score for hip fractures below $3 \%$. Regarding the risk factors studied, women with a history of rheumatoid arthritis who currently use corticosteroids have the highest risk of fractures with a FRAX score for major osteoporotic fractures $\geq 20 \%$ and a FRAX score for hip fractures $\geq 3 \%$.
\end{abstract}

Key words: FRAX, fracture risk, women, menopause

\section{INTRODUCTION}

Osteoporosis is a metabolic bone disease characterized by low bone mass and deterioration of bone microarchitectonics, leading to increased fracture risk. Osteoporotic fractures are one of the causes of disability and mortality in the elderly population. While postmenopausal osteoporosis occurs due to low estrogen levels, the cause of senile osteoporosis is low levels of vitamin D3 [1, 2]. Bone mass alone cannot explain the risk of fractures in all cases [3]. The existence of patients with osteoporosis but without fractures and those with osteopenia but with multiple fractures proves that bone mineral density (BMD) alone is not a sufficient indicator for predicting fracture risk. It is estimated that women with scoliosis have higher fracture risk [4]. Using algorithms of computer vision we can easier detect patients with scoliosis and can better make decision about their fracture risk $[5,6,7]$.

Globally, there are several tools for fracture risk assessment $[8,9]$. The most popular is the Fracture Risk Assessment Tool (FRAX), which is available for free online. The FRAX algorithm is a web-based tool (www.shef.ac.uk/FRAX), published in 2008 by the University of Sheffield and developed to calculate the 10-year probability for major osteoporotic fracture (MOF) and for hip fracture (HF) based on clinical risk factors and BMD. According to the National Osteoporosis Foundation, treatment is recommend- ed for patients with BMD of the lumbar spine, femoral neck or total hip corresponding to osteoporosis. For patients with osteopenia (with T-score between $-1.0 \mathrm{SD}$ and -2.5 SD), treatment is recommended for all ages and genders with FRAX MOF $\geq 20 \%$ and with FRAX HF $\geq 3 \%[10,11,12,13]$.

The aim of this study is to evaluate the characteristics of patients with FRAX MOF $\geq 20 \%$ and with FRAX $\mathrm{HF} \geq 3 \%$ using the innovative REMS technology.

\section{PATIENTS AND METHOdS}

101 postmenopausal women aged 65 years \pm 11 years (SD), (range 43-87) were included in the study. Women were divided into 2 groups according to the fracture risk: 1st - with FRAX MOF below 20\% and FRAX HF below $3 \%$, and 2nd - with FRAX MOF $\geq 20 \%$ and FRAX HF $\geq 3 \%$. FRAX score has been calculated without inclusion of the value of bone mineral density. Information is collected for the following risk factors - previous fractures, diagnosed rheumatoid arthritis (RA), smoking, use of glucocorticoids (GC) and alcohol consumption of more than $30 \mathrm{ml}$ alcohol daily.

\section{StATISTICAL ANALYSIS}

A chi-square test was used to assess whether there is a significant difference between risk factors in the two groups. A descriptive statistical analysis 
was used to describe the characteristics of both groups. Student's T-test for independent samples was used to assess the association between a quantitative and qualitative variable, and the chi-square test for two qualitative variables.

\section{Results}

$65.4 \%$ of the women (66/101 women) have FRAX score for MOF below $20 \%$ and $34.6 \%$ have FRAX score for MOF $\geq 20 \%$. 48.5\% (49/101) of the women have FRAX score for hip fractures (HF) below $3 \%$ and $51.5 \%$ have FRAX score for $\mathrm{HF} \geq 3 \%$. Women with FRAX MOF $\geq 20 \%$ and FRAX HF $\geq 3 \%$ were significantly older (mean age 73 years, respectively 72 years) than those with FRAX MOF below $20 \%$ and FRAX HF $<3 \%$ (mean age 62 years, respectively 59 years), $(p=0.000)$. The mean weight and height of the women with FRAX MOF $\geq 20 \%$ and with FRAX HF $\geq 3 \%$ were significantly lower (mean weight $60.6 \mathrm{~kg}$ for FRAX MOF $\geq 20 \%$, respectively $61.39 \mathrm{~kg}$. for $\mathrm{FRAX} \mathrm{HF} \geq 3 \%$, and mean height 151.7 $\mathrm{cm}$ for FRAX MOF $\geq 20 \%$ and $153.2 \mathrm{~cm}$ for FRAX $\mathrm{HF} \geq 3 \%$ ) of those women with FRAX MOF below $20 \%$ and FRAX HF < 3\% (mean weight $69.4 \mathrm{~kg}, 71.7$ $\mathrm{kg}$, mean height $158.75 \mathrm{~cm}$ and $159.67 \mathrm{~cm}$, respectively), $(p=0.003$ for the weight and $p=0.000$ for the height), $(p=0.000)$, (Table 1).

Comparing risk factors: previous fractures, smoking, use of corticosteroids (CS), rheumatoid arthritis (RA) and alcohol consumption of more than 30 $\mathrm{ml}$. alcohol daily in the groups formed according to the fracture risk, we established a statistically significant relationship for the risk factors: previous fractures, use of CS and history of RA. The ratio (women with previous fractures) / (women without previous fractures) is significantly higher in the groups with FRAX score for MOF $\geq 20 \%$ (3.25) and with FRAX score for $\mathrm{HF} \geq 3 \%$ (1.55) compared to the groups with FRAX MOF $<20 \%$ (0.40) and FRAX HF < 3\% (0.4), $p=0.000$, comparing women with fractures between the gropups according to FRAX MOF and $p=0.001$, comparing the women with fractures between the groups according to FRAX HF. There is no statistically significant difference in the number of smokers and non-smokers, as well as in the number of women who consume more than $30 \mathrm{ml}$. alcohol per day compared to those who don't consume any alcohol or consume smaller amounts of alcohol daily between the groups according to FRAX MOF ( $p=$ 0.342) and according to FRAX HF (0.953). Corticosteroid use and diagnosis of RA are significant risk factors for FRAX MOF $\geq 20(p=0.010$ and $p=0.017$, respectively) and for FRAX HF $\geq 3 \%,(p=0.044$ and $p=0.026$, respectively). The ratios (women using CS) / (women without CS) and (women with RA) / (women without RA) were significantly higher in the groups with MOF $\geq 20 \%$ ( 0.36 for CS and 0.62 for RA) and with FRAX HF $\geq 3 \%$ (0.24 for CS and 0.5 for RA) compared to the groups FRAX MOF $<20 \%$ ( 0.08 for CS and 0.2 for RA) and FRAX HF $<3 \%$ (0.09 for CS and 0.16 for RA), (Table 2 ).

Table 1. Student's t-test for independent samples to compare age, weight, height and BMI between the two groups; FRAX risk groups: MOF-major osteoporotic fracture, HF-hip fracture

\begin{tabular}{|c|c|c|c|c|c|c|}
\hline \multirow{9}{*}{ FRAX MOF } & & FRAX & $\mathrm{N}$ & Mean value & Standard deviation & $\mathrm{p}$-value \\
\hline & \multirow{2}{*}{ Age (years) } & $<20 \%$ & 66 & 62 & 8.918 & \multirow{2}{*}{0.000} \\
\hline & & $\geq 20 \%$ & 35 & 73 & 8.161 & \\
\hline & \multirow{2}{*}{ Weight(kg) } & $<20 \%$ & 66 & 69.41 & 14.788 & \multirow{2}{*}{0.003} \\
\hline & & $\geq 20 \%$ & 35 & 60.68 & 10.221 & \\
\hline & \multirow{2}{*}{ Height (cm) } & $<20 \%$ & 66 & 158.75 & 7.7946 & \multirow{2}{*}{0.000} \\
\hline & & $\geq 20 \%$ & 35 & 151.694 & 6.0236 & \\
\hline & \multirow{2}{*}{ BMDFN (g/cm2) } & $<3 \%$ & 49 & 59 & 7.464 & \multirow{2}{*}{0.000} \\
\hline & & $\geq 3 \%$ & 52 & 72 & 7.860 & \\
\hline \multirow{8}{*}{ FRAX HF } & \multirow{2}{*}{ Age (years) } & $<3 \%$ & 49 & 71.69 & 15.330 & \multirow{2}{*}{0.00} \\
\hline & & $\geq 3 \%$ & 52 & 61.39 & 10.431 & \\
\hline & \multirow{2}{*}{ Weight(kg) } & $<3 \%$ & 49 & 159.67 & 7.9199 & \multirow{2}{*}{0.00} \\
\hline & & $\geq 3 \%$ & 52 & 153.16 & 6.6217 & \\
\hline & \multirow{2}{*}{ Height (cm) } & $<20 \%$ & 66 & 62 & 8.918 & \multirow{2}{*}{0.000} \\
\hline & & $\geq 20 \%$ & 35 & 73 & 8.161 & \\
\hline & \multirow{2}{*}{ BMDFN $\left(\mathrm{g} / \mathrm{cm}^{2}\right)$} & $<20 \%$ & 66 & 69.41 & 14.788 & \multirow{2}{*}{0.003} \\
\hline & & $\geq 20 \%$ & 35 & 60.68 & 10.221 & \\
\hline
\end{tabular}


Table 2. Chi-square test for the significance of the risk factors in both groups

\begin{tabular}{|c|c|c|c|c|c|c|c|}
\hline & & \multicolumn{2}{|c|}{ FRAX MOF } & \multirow{3}{*}{ p-value } & \multicolumn{2}{|c|}{ FRAX HF } & \multirow{3}{*}{ p-value } \\
\hline \multirow{2}{*}{\multicolumn{2}{|c|}{ Risk factors }} & $<20 \%$ & $\geq 20 \%$ & & $<3 \%$ & $\geq 3 \%$ & \\
\hline & & Count & Count & & Count & Count & \\
\hline \multirow{2}{*}{ Previous fractures } & yes & 36 & 32 & \multirow{2}{*}{0.000} & 28 & 40 & \multirow{2}{*}{0.001} \\
\hline & no & 111 & 10 & & 90 & 31 & \\
\hline \multirow{2}{*}{ Smoking } & yes & 38 & 5 & \multirow{2}{*}{0.342} & 32 & 11 & \multirow{2}{*}{0.110} \\
\hline & no & 109 & 37 & & 86 & 60 & \\
\hline \multirow{2}{*}{ Use of corticosteroids } & yes & 17 & 14 & \multirow{2}{*}{0.010} & 13 & 18 & \multirow{2}{*}{0.044} \\
\hline & no & 130 & 28 & & 105 & 53 & \\
\hline \multirow{2}{*}{ Rheumatoid arthritis } & yes & 34 & 19 & \multirow{2}{*}{0.017} & 26 & 27 & \multirow{2}{*}{0.026} \\
\hline & no & 113 & 23 & & 92 & 44 & \\
\hline \multirow{2}{*}{ Alcohol consumption more than $30 \mathrm{ml}$ daily } & yes & 12 & 2 & \multirow{2}{*}{0.575} & 10 & 4 & \multirow{2}{*}{0.953} \\
\hline & no & 135 & 40 & & 108 & 67 & \\
\hline
\end{tabular}

\section{Discussion}

The need for adequate treatment of patients at high risk of fractures brings to the fore the need for new models to predict this risk. The FRAX algorithm, launched by the WHO in 2008, is a fracture risk assessment tool that gives a 10 -year probability of major osteoporotic fractures and hip fractures [14, 15]. The clinical risk factors included in the FRAX model are, on the one hand, easily accessible and, on the other hand, strictly validated by evidence-based medicine [16]. In the present study, the ability to assess 10-year fracture risk with REMS technology, which has integrated FRAX software [17], motivates us to describe the characteristics of patients in different risk groups according to FRAX, using this innovative method.

The results of the study show that age is an important risk factor for MOF and HF and that there is a statistically significant difference in age between the groups. The effect of the age on risk assessment with FRAX is consistent with data provided by the National Osteoporosis Group [18]. In a study by Gadam et al., age was the only risk factor in postmenopausal women which differed significantly between identical and non-identical predictions [19, 20,21, 22].

Weight and height were significant risk factors for FRAX MOF $\geq 20 \%$ and for FRAX HF $\geq 3 \%$ in the study. Similar results have been observed in other studies [23, 24, 25].

Although low BMD values are crucial for osteoporotic fractures, some fracture cases are characterized by BMD that is not in the range of osteoporosis $[26,27]$. According to Kanis et al., the prediction of fractures only through clinical risk factors and without the inclusion of BMD in the FRAX algorithm is comparable to that with the inclusion of BMD. In the present study, patients with lower BMD showed a significantly higher FRAX score for MOF and HF, which is in agreement with other studies [28].

According to our study, the presence of previous fractures is significant for FRAX MOF $\geq 20 \%$ and for FRAX HF $\geq 3 \%$. In the study of Morin et al., nontraumatic fractures in women were associated with osteoporosis of the femoral neck, and the authors showed that the location of previous fractures affected future fracture risks, regardless of BMD values [28].

Rheumatoid arthritis is included as a dichotomous predictor in the WHO FRAX algorithm for predicting the 10-year risk of hip or major osteoporotic fractures. In our study, RA was a significant factor for FRAX MOF and FRAX HF. Several studies have shown, in agreement with our study, that the incidence of fractures is higher in patients with RA $[29,30]$.

The use of corticosteroids (CS) is also used in the FRAX model. They affect fracture risk regardless of bone density. According to Kanis et al., the use of these drugs is a significant factor for fracture probability. Fracture probabilities increase by $15 \%$ for high doses of CS (> $7.5 \mathrm{mg}$ daily) $[29,30]$.

\section{Conclusion}

Adult postmenopausal women with low BMD, low weight and height, previous fractures, rheumatoid arthritis and corticosteroids have the highest risk of fractures with FRAX MOF $\geq 20 \%$ and FRAX HF $\geq 3 \%$.

\section{Библиография / References}

1. Abedinov F, Bakalova N, Krastev P et al. Survival and Quality of Life of Patients with a Prolonged Stay in the Intensive Care Unit after Cardiac Surgeries-Remote Results. Copt. Rend. Acad. Bulg. Sci. 2019 Jan 1;72:1130-6. 
2. Кирилов Н, И. Шейтанов И.. Хранителен статус при възрастни жени с ниско ниво на витамин D и остеопороза. Science \& echnologies. Volume viii, 2018, number 1: medical bi-ology studies, clinical studies, social medicine and health care, 60-66.

3. Buchbinder R, Johnston RV, Rischin KJ et al. Percutaneous vertebroplasty for osteoporotic vertebral compression fracture. Percutaneous vertebroplasty for osteoporotic vertebral compression fracture. Cochrane Database Syst Rev. 2018.

4. Kirilov N, Todorov S, Nikolov N, Nikolov M. Comparsion of The Fracture Risk in Women With and Without Scoliosis Through Dual-Energy X-RAY Absoprtiometry, Eular 2020, Ard, Ann Rheum Dis, volume 79, supplement 1.

5. Kirilov N. Mobile health Applications for Management of Musculoskeletal Diseases 2020,Industrial Technologies 7, Vol 1,80-83.

6. Kirilov N. Application of CANNY algorithm in computer vision. Industrial Technologies 2020;7,1,75-80.

7. Kirilov N, Kirilova E. Computer vision for assessment of scoliosis from dual energy X-ray (DXA) image Сборник доклади, стр. 18, Втора научна сесия „Биомедицина и качество на живот“ за млади учени, докторанти и постдокторанти в чест на 150-та годишнина на Българска академия на науките.Институт по биофизика и биомедицинско инженерство - БАН 4-5 ноември 2019.

8. Kanis JA, McCloskey EV, Johansson $\mathrm{H}$ et al. Scientific Advisory Board of the European Society for Clinical and Economic Aspects of Osteoporosis and Osteoarthritis (ESCEO) and the Committee of Scientific Advisors of the International Osteoporosis Foundation (IOF). 2013.

9. Kanis JA, on behalf of the World Health Organization Scientific Group. Assessment of osteoporosis at the primary health-care level. Technical Report. World Health Organization Collaborating Centre for Metabolic Bone Diseases, University of Sheffield; UK: 2007.

10. Kanis JA, Harvey NC, Cooper C, et al. A systematic review of intervention thresholds based on FRAX: A report prepared for the National Osteoporosis Guideline Group and the International Osteoporosis Foundation. Arch Osteoporos. 2016;11(1):25. doi:10.1007/s11657-016-0278-z

11. Kanis JA, Johnell O, Oden A et al. FRAX and the assessment of fracture probability in men and women from the UK. Osteoporos. Int. 2008, 19, 385-397.

12. Kanis JA, McCloskey E, Johansson $H$ et al. FRAX with and without bone mineral density. Calcif. Tissue Int 2012, 90, 1-13.

13. Aubry-Rozier B, Stoll D, Krieg MA et al. What was your fracture risk evaluated by FRAX® the day before your osteoporotic fracture. Clin Rheumatol 2013;32:219-23. [CrossRef]

14. Bolland MJ, Grey A, Gamble G, Reid IR. Comment on Kanis et al.: Pitfalls in the external validation of FRAX. Osteoporos Int 2013;24:389- 90. [CrossRef]

15. Gadam RK, Schlauch K, Izuora KE. Frax prediction without BMD for assessment of osteoporotic fracture risk. EndocrPract. 2013;19(5):780-784. doi:10.4158/EP12416.OR.

16. Klop C, de Vries F, Bijlsma JWJ, et al. Predicting the 10-year risk of hip and major osteoporotic fracture in rheumatoid arthritis and in the general population: an independent validation and update of UK FRAX without bone mineral density. Annals of the Rheumatic Diseases 2016; 75:2095-2100.

Постъпила за печат: 13.11.2021 2.

$\triangle$ Адрес за кореспонденция:

Д-р Елена Кирилова Кирилова

Университет "Проф. Д-р Асен Златаров"

ул. „Проф. Якимов“ 1

8010 Бургас

тел. 0884623614
17. Armstrong ME, Spencer EA, Cairns BJ et al. Body mass index and physical activity in relation to the incidence of hip fracture in postmenopausal women. J Bone Miner Res. 2011;26(6):1330-8. doi: 10.1002/jbmr.315.

18. Gao G, Zhang ZL, Zhang $\mathrm{H}$ et al. Hip axis length changes in 10,554 males and females and the association with femoral neck fracture. J Clin Densitom. 2008;11(3):360-6. doi: 10.1016/j. jocd.2008.04.005. [PubMed] [CrossRef] [Google Scholar]

19. World Health Organisation. WHO Technical Report Series 843. In Assessment of Fracture Risk and its Application to Screening for Postmenopausal Osteoporosis; WHO: Geneva, Switzerland, 1994.

20. Nguyen ND, Eisman JA, Center JR, Nguyen, TV. Risk factors for fracture in nonosteoporotic men and women. J. Clin. Endocrinol. Metab. 2007, 92, 955-962. Osteoporos Int. 2013 Jan; 24(1):23-57.

21. Pasco JA, Seeman E, Henry MJ et al. The population burden of fractures originates in women with osteopenia, not osteoporosis. Osteoporos. Int. 2006, 17, 1404-1409.

22. Prawiradilaga RS, Gunmalm V, Lund-Jacobsen T, et al. FRAX Calculated without BMD Resulting in a Higher Fracture Risk Than That Calculated with BMD in Women with Early Breast Cancer. J Osteoporos. 2018;2018: 4636028. Published 2018 Oct 4. doi:10.1155/2018/4636028

23. Briot K, Paternotte $S$, Kolta $S$, et al. FRAX®: prediction of major osteoporotic fractures in women from the general population: the OPUS study. PLoS One. 2013;8(12):e83436.

24. Marques $A$, Lucas $R$, Simões $E$, et al. Do we need bone mineral density to estimate osteoporotic fracture risk? A 10-year prospective multicentre validation study. RMD Open 2017;3: e000509. doi: 10.1136/rmdopen-2017-000509.

25. Morin SN, Lix LM, Leslie WD. The importance of previous fracture site on osteoporosis diagnosis and incident fractures in women. J Bone Miner Res. 2014 Jul;29(7):1675-80. doi: 10.1002/jbmr.2204.

26. Kim SY, Schneeweiss S, Liu J, et al. Risk of osteoporotic fracture in a large population-based cohort of patients with rheumatoid arthritis. Arthritis Res Ther. 2010;12(4): R154. doi:10.1186/ar3107.

27. Terpos E, Fragiadaki K, Konsta M et al, Sfikakis P.P. Early effects of IL-6 receptor inhibition on bone homeostasis: a pilot study in women with rheumatoid arthritis. 2011.

28. Van Staa TP, Geusens P, Bijlsma JW, Leufkens HG, Cooper C. Clinical assessment of the long-term risk of fracture in patients with rheumatoid arthritis. Arthritis Rheum, 54 (2006), pp. 3104-3112.

29. Leib ES, Saag KG, Adachi JD et al. FRAX(®) Position Development Conference Members. Official Positions for FRAX clinical regarding glucocorticoids: the impact of the use of glucocorticoids on the estimate by FRAX of the 10-year risk of fracture from Joint Official Positions Development Conference of the International Society for Clinical Densitometry and International Osteoporosis Foundation on FRAX. J ClinDensitom. 2011 JulSep;14(3):212-9. doi: 10.1016/j.jocd.2011.05.014.

30. Kanis JA, Johansson H, Oden A, McCloskey EV. Guidance for the adjustment of FRAX according to the dose of glucocorticoids. Osteoporos Int. 2011 Mar;22(3):809-16. doi: 10.1007/s00198-010-1524-7. Epub 2011 Jan 13.

Submitted: 13.10 .2021

Correspondence address:

E. K. Kirilova, MD

University "Prof. Dr. Assen Zlatarov"

1 Prof. Yakimov str.

8010 Burgas

tel. 0884623614 